\title{
NONLINEAR BOUNDARY VALUE PROBLEMS FOR IMPULSIVE DIFFERENTIAL EQUATIONS WITH CAUSAL OPERATORS
}

\author{
WENLI WANG AND JINGFENG TIAN
}

\begin{abstract}
In this work, we investigate nonlinear boundary value problems for impulsive differential equations with causal operators. Our boundary condition is given by a nonlinear function, and more general than ones given before. To begin with, we prove a comparison theorem. Then by using this theorem, we show the existence of solutions for linear problems. Finally, by using the monotone iterative technique, we obtain the existence of extremal solutions for nonlinear boundary value problems with causal operators. An example satisfying the assumptions is presented.
\end{abstract}

Mathematics subject classification (2010): 34B37.

Keywords and phrases: nonlinear boundary value problems, causal operators, monotone iterative technique, extremal solutions.

\section{REFERENCES}

[1] D. D. Bainov, V. Lakshmikantham and S. Simeonov, Theory of impusulsive differential equations, World Scientific Press, Singapore, 1989.

[2] D. Chen AND B. DAI, Periodic solution of second order impulsive delay differential systems via variational method, Appl. Math. Lett., 38, 38 (2014), 61-66.

[3] D. Drici, F.A. MCRAe AND J.V. DeVI, Differential equations with causal operators in a Banach space, Nonlinear Anal., 62, 2 (2005), 301-313.

[4] D. DRICI, F.A. MCRAE AND J.V. DeVI, Monotone iterative technique for periodic boundary value problems with causal operators, Nonlinear Anal., 64, 6 (2006), 1271-1277.

[5] F. GENG, Differential equations involving causal operators with nonlinear periodic boundary conditions, Math. Comput. Model., 48, 5-6 (2008), 859-866.

[6] Z. HE AND J. YU, Periodic boundary value problem for first-order impulisive ordinary differential equations, Comput. Math. Appl., 272, 2 (2002), 205-217.

[7] T. JANKOWSHI, Boundary value problems with causal operators, Nonlinear Anal., 68, 12 (2008), 3625-3632.

[8] G. S. Ladde, V. Lakshmikantham and A. S. Vatsala, Monotone Iterative Techniques for Nonlinear Differential Equations, Pitman, London, 1985.

[9] V. Lakshmikantham, S. Leela, Z. Drici and F. A. MCRae, Theory of causal differential equations, World Scientific Press, Paris, 2009.

[10] X. YANG AND J. SHEN, Nonlinear boundary value problems for first order impulsive functional differential equations, Appl. Math. Comput., 189, 2 (2007), 1943-1952.

[11] X. Liu, S. Sivaloganathan And S. Zhang, Monotone iterative techniques for time-dependent problems with applications, J. Math. Anal. Appl., 237, 1 (1999), 1-18.

[12] Z. LuO AND Z. JING, Periodic boundary value problem for first-order impulsive functional differential equations, J. Comput. Appl. Math., 138, 2 (2002), 205-217.

[13] P. WANG, S. TIAN AND Y. WU, Monotone iterative method for first-order functional difference equations with nonlinear boundary value conditions, Appl. Math. Comput., 203, 1 (2008), 266-272.

[14] P. WANG AND J. ZHANG, Monotone iterative technique for initial-value problems of nonlinear singular discrete systems, J. Comput. Appl. Math., 221, 1 (2008), 158-164. 
[15] P. Wang And M. Wu, Practical $\phi_{0}$-stability of impulsive dynamic systems on time scales, Appl. Math. Lett., 20, 6 (2007), 651-658.

[16] W. WANG AND J. TIAN, Generalized monotone iterative method for nonlinear boundary value problems with causal operators, Bound. Value Probl., 2014, 1 (2014), 1-12.

[17] W. WANG AND J. TIAN, Difference equations involving causal operators with nonlinear boundary conditions, J. Nonlinear Sci. Appl., 8, 3 (2015), 267-274.

[18] W. WANG AND J. TIAN, Generalized monotone iterative method for integral boundary value problems with causal operators, J. Nonlinear Sci. Appl., 8, 4 (2015), 600-609.

[19] Z. Wei AND C. PANG, Periodic boundary value problems for second order functional differential equations, J. inequal. Appl., 56, 1 (2010), 2065-2072.

[20] Y. ZHAO, G. SONG AND X. SUn, Integral boundary value problems with causal operators, Comput. Math. Appl., 59, 8 (2010), 2768-2775. 